\title{
Knowing Coffee and Smoking Laws through Literary Texts in Irshädu al- Ikhwānu li Bayāni Shurbi al-Qahwati wa ad-Dhukhāni by Sheikh Ihsan ibn Dahlan Jampes
}

\author{
Devina Gary Oktiana, Maman Lesmana \\ Arabic Studies Program, Faculty of Humanities, Universitas Indonesia
}

\begin{abstract}
The book Irshādu al-Ikhwānu li bayāni Shurbi al-Qahwati wa ad-Dhukhāni, one of the books written by Sheikh Ihsan ibn Dahlan Jampes, discusses the law of coffee drinking and smoking cigarettes. Like otherkitab kuning(specific religious books regarding laws), this book is presented in the form of literary texts, startingin the form of poetry and then explained in the form of prose, in order to appeal readers. This article aims to look at the structure and content of literary texts used in the book, to see how effective it is in providing information about coffee drinking laws and smoking cigarettes among Muslims. To discuss this, this article uses bibliographic data, both as a research corpus and a reference, and qualitative method, which prioritises words rather than numbers and emphasisesquality over quantity. The data are then presented in the form of descriptive analysis using semiotic structuralism methods. From the results of the research, it is found that this book uses classic poetry and prose texts in conveying information about the law of coffee drinking and smoking, but the rhetorical elements used in the textsconsist of more denotative words rather than connotative ones, as well as literal words rather than figurative ones, thus making it easier to digest and more effective to use as a means of providing information to the reader.
\end{abstract}

Keywords:- Sheikh Ihsan ibn Dahlan Jampes, literature, cigarettes, coffee

\section{INTRODUCTION}

The book Irshādu al-Ikhwānu li Bayāni Shurbi al-Qahwati wa ad-Dhukhāni is one of the books written by Sheikh Ihsan ibn Dahlan Jampes which discusses coffee and cigarettes. In his book he uses literary texts to remove the impression of tedium and complexity. He combines the beauty of poetry and prose in conveying his thoughts. The book is very popular among scholars as it contains a discussion of the history of coffee and cigarettes followed by its laws which have become a matter of disputes among scholars, thus giving space to readers to determine their own choice regarding the matter.

Polemics about the laws of coffee drinking and smoking has indeed become an endless debate among scholars and their students. In this book, the lawsare presented in a simple and beautiful mannerdue to the skill of an expert in the art of writing Arabic rhymes (Hadi, 2008: 22). The book does not only contain the thoughts of Sheikh Ihsan alone, but it also includes the excerpts of the thoughts of other scholars of both past and contemporaries by quoting various references. The author of the book succeeds in serving the readers a very heavy content with a beautiful composition of poetry. (Jampes, 2013: 2). This book is also very richin Sufistic charm, considering that the authorwas indeed a Sufi who lived the life of Sunni tasawuf, through his interpretation of the Sufism of Imam al-Ghazali (Wasid, 2016: 27).

Sheikh Ihsan Jampes was one of Indonesian scholars who have a strong and deep image in his works. It is not surprising that his works are so extraordinary, judging from his activities and his family background that almost all of them were Islamic leaders (Hadi, 2008: 
1). Bornas the son of a great kiai founder of Jampes pesantren in East Java (1886 AD), Sheikh Ihsan was accustomed to living in pesantren(Indonesian Islamic schools) environment which was wealthyin religious knowledge. In addition, he was also accustomed to study tours to other pesantren in order to deepen the knowledge that he had or toenrich his knowledge (Murtadho, 2009: xv).

Sheikh Ihsan Jampes's full name was Sheikh Ihsan ibn Dahlan ibn Saleh Jampes and was called Bakri in his childhood. He was born in 1901 AD in the Jampes pesantren neighborhood, Putih village, Gampengrejo district, Kediri, East Java. His parents were K.H. Dahlan ibn Saleh and Madam Artimah. He passed away in September 1952 (Murtadho, 2009: xxii). His father, K.H. Dahlan founder of Jampes pesantren (1886 AD) was the son of KH. Saleh, a scholar from Bogor, West Java, who had the lineageof Sunan Gunung Jati (Sharif Hidayatullah) Cirebon. His grandmother, Madam Istianah also had a strong bloodline to Muslim family. His father, an Egyptian Kiai from the village of Durenan Trenggalek district was the son of a kiai famous for his supernatural powers inheritedfrom his Panembahan Senopati ancestor, the founder of Mataram Kingdom, namely Kiai Yahuda from Lorog Pacitan. Madam Istianah was also a granddaughter of Kiai Ageng Hasan Besari, the founder of Pesantren Tegalsari Ponorogo, who was a descendant of Sunan Ampel. (Wasid, 2016: 3031). His work on coffee was inspired from his daily life as he was very fond of coffee and cigarettes. Although there are many different views regarding the laws on the matter, his courage in exploring his ability made him able to explore thoroughly the problems surrounding coffee and cigarette laws that he expressed it in his writing as a classic literary work in the form of a book, or more familiarly called the kitab kuning. (Hadi, 2008: 49) This also makes his work appealingon its own for profound analysis and research.

The Book Irshad al-Ikhwan fi Bayan Hukmi Shurb al-Qahwah wa ad-Dukhan is a poetic adaptation and an explanation of Tadzkirah al-Ikhwan fi Bayani al-Qahwah wa ad-Dukhan by KH. Ahmad Dahlan of Semarang. Although his other books are only labeled sharh (explanation), in this book Sheikh Ihsan provides many other references that he found and inserts his thoughts based on his deep knowledge, and then he delivers it in the form of classic poetry as a form of exploration of his ability in the art of Arabic rhyme writing, thus making this book a masterpiece of his.

In addition to discussing the exact origins of coffee and cigarettes in the book, Sheikh Ihsan also writes various benefits of coffee and cigarettes, as well as opinions from among the scholars who forbid cigarettes and coffee as well as their reasons and opinions which allow the use of coffee and cigarettes within the Islamic jurisprudence related to coffee and cigarettes.Because of the abundance of data contained in the book, this article only covers literary texts in which the words cigarettes and coffee are present.

\section{ANALISYS AND DISCUSSION}

As mentioned in the introduction, this book consists of prose and poetry. Looking at its forms of literary, the prose contained in this book is Al-Nasir al-Fanni, a form of prose in Arabic that uses the means of art and does not use the language of everyday conversation or dry scientific language; it uses the style of language which words, phrases, and sentences are highly aesthetic or so-called 'highly writing' (Lesmana, 2009: 13). This book also uses a lot of high aesthetic elements in expressing opinions and data.In addition, the book also uses al$u s l \bar{u} b$ al-khitäbi, which is one of the styles of prose writing characterisedby the repeating of certain words or sentences that serve as emphasis, using of synonyms to clarify meanings, and giving examples of problems in the text (Al-Jarim, 2013: 16). Sheikh Ihsan uses this style to describe various problems concerning coffee and cigarettes in detail, in order to deliver 
data and explore a problem clearly with a literary dressing. He takes into account the balance of clear and accurate contexts and the beauty in his delivery.

Aside of these two styles, the book also uses uslübmustamirrun mutarradun, the style in Arabic prosecharacterised by the absence of punctuations (Lesmana, 2009: 13). The use of this style is very common in the writing of kitab kuning or classic Arabic books, in addition to using an Arabic script written withoutvowel marks or harakat. The connection of one sentenceanother is markedby the addition of particles such as $ث$, و, etc. This is actually very difficult for readers who are not accustomed to reading such writing. It is feared that misunderstandings will result from misplacing punctuationsin the sentences.

Examples of such styles are as follows:

\begin{tabular}{|c|}
\hline ون أنهم (فاخليسـ \\
\hline $\begin{array}{l}\text { Differences of opinionsin the forbidden and permissible aspects that occurred } \\
\text { among the scholars have lasted for a long time. They propose arguments as the } \\
\text { means to strengthen their opinions. A cigarette known as al-tanbāk, a name } \\
\text { from outside Arabia,was known among the companions as mentioned by Al- } \\
\text { Nābilīsī. After more and more disputes about the law of smoking, some of them } \\
\text { took the stance to determine whether smoking is permissible or forbidden, as } \\
\text { found in Fatāwā al-Kurdiy. }\end{array}$ \\
\hline
\end{tabular}

This text actually consists of three sentences. Each sentence is not endedwith a full stop, nor ineach sentence is marked by a comma. The first sentence and the second sentence are connected using the particle (g), such as the following text:

\begin{tabular}{|c|c|c|}
\hline 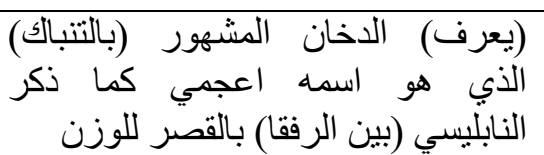 & و & 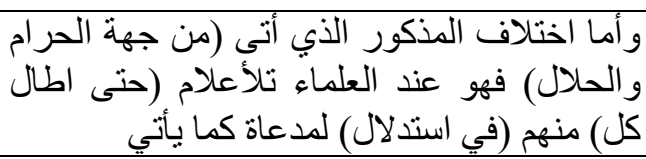 \\
\hline
\end{tabular}

The second sentence and the third sentence are also connected using the particle (و), such as the following text:

\begin{tabular}{|c|c|c|}
\hline 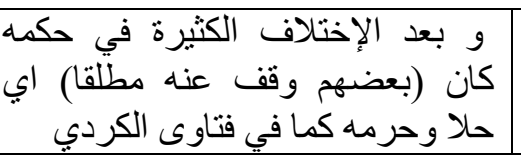 & و & 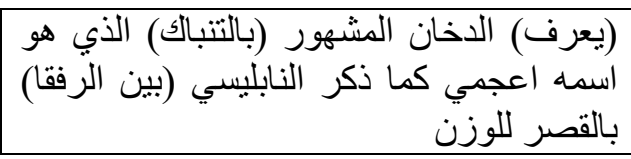 \\
\hline
\end{tabular}

Meanwhile, the form of poetry used in this book is the classic form of Arabic poetry. This can be seen from its poem form being divided into two parts, where one verse (in Classic arabic poetry) consists of only one line and there is no line breaks of enjambment, as it usually is only present in modern poetry, such as the following text:

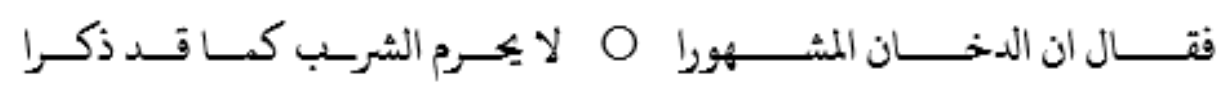

\begin{tabular}{|c|c|}
\hline $\begin{array}{c}\text { Là yahrumu al-Shurba kamā qad } \\
\dot{z} u k i r \bar{a}\end{array}$ & Faqāla inna ad-dukhāna al-masyhūrāa \\
\hline It is not forbidden to smoke as it & Thus he said that the real cigarette is \\
\hline
\end{tabular}




\begin{tabular}{|l|l|}
\hline has been mentioned. & indeed famous \\
\hline
\end{tabular}

This verse explains the opinion of a scholar who says that it is not forbidden to smoke cigarettes. The Arabic rhetorical tool used in this verse is 'ilmu al-ma'ani, which is the study of how to convey a statement according to the circumstances. 'Ilmu Al-Ma'anidiscusses the origin of the statement for a particular purpose and its application as required. (Shaykh, 1989: 17). 'Ilmu Al-Ma'aniis divided into two major aspects, namely kaläm al-khabar and kalam al-insha $\bar{a}^{\prime}$. In the language perspective, kalām al-khabar can be paired with an informative sentence, while kalam al-insh $\bar{a}^{\prime}$ is not an informative sentence. In a broader sense, kaläm alkhabar can be interpreted as a statement that may contain true or false information. If the sentence is in accordance with reality, then the information is true, whereas if the sentence is not in accordance with the reality, it means that the information is fabricated (Al-Jarim, 2013: 377).

Kalam al-khabar has several purposes. One of them is fa'idat al-khabar, when the speaker conveys an information that has not been known by the hearer, or in other words, only gives information to the hearer. (Shaleh 1983: 29) As seen in the text, in order to provide the information, this verse uses the 'inna, am affirming particle, before the noun addukhan (cigarette) and qad before the verb zukira(mentioned). The use of these supporting particles is intended to inform the other person that this statement is indeed true and there is no doubt in it. In Arabic rhetoric, this type of language is also called kalam al-khabar alinkari, an informative sentence addressed to the hearer who does not believe in the information conveyed (Syarifudin, 2016: 237).

The other rhetorical tool used in this verse is the $s a j^{\prime}$ (rhyme) /-a/ at the end of the line. Saj'is the matching of the sounds in the final letter of two or more lines (Al-Jarim, 2013: 391). In the Arabic grammatical rules, there is actually no additional sound /-a/ behind the word /al-mashural and the word /zukiral, but for the sake ofthe same rhyme at the end of the verse, the vowel sound /-a/ is added. This is called licentia poetica. Shaw says (in Hadi, 2015) that licentia poetica is a writer's freedom to deviate from reality, from conventional forms or rules to produce the desired effects. The discussion of rhyme in Arabic rhetoric is included in 'ilmu al-badi', which is the study of how to beautify a word or phrase (Lesmana, 2010: 143).

In addition to kalam al-khabar al-'inkari, there is a rhetoric aspect called kaläm alkhabar al-'ibtida' $i$ which is defined as a statement addressed to a group of people who have no doubt or oppose the information conveyed (Syarifudin, 2016: 234). This is delivered in the following text:

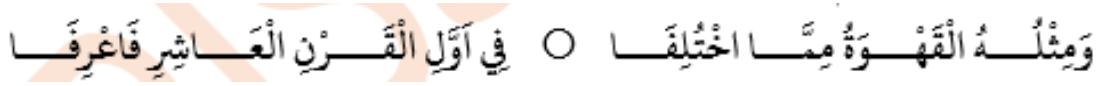

\begin{tabular}{|c|c|}
\hline $\begin{array}{c}F \bar{\imath} \text { awwali al-qarni al- 'àsyiri fa } \\
\text { a'rifā }\end{array}$ & Wa misiluhu al-qahwatu mimmā ukhtulifā \\
\hline $\begin{array}{c}\text { At the beginning of the tenth } \\
\text { century then know that }\end{array}$ & $\begin{array}{c}\text { as well as smoking, there is a difference } \\
\text { (of opinion) regarding coffee }\end{array}$ \\
\hline
\end{tabular}

This verse explains that in addition to smoking, there are differences of opinion regarding the law of coffee drinking. This verse is the same as the previous one regarding its purpose to provide ordinary information, but unlike the previous verse, this one does not use any emphasis particle at all. This statement is called kalām khabar al-'ibtidā'i. According to Salih (in Lesmana, 2009: 29) al-'ibtida $\bar{a}^{\prime} i$ is a group of people who readily acceptthe 
statementsdelivered by the addresee. Therefore, there is no need to use emphasis particles because the hearer is considered to readily believe what the addresee says. As in the previousverse, at the end of this verse also has the same rhyme /-a/ which is the licentia poetica of the author.

Anotherverse that discusses about smoking is the following text:

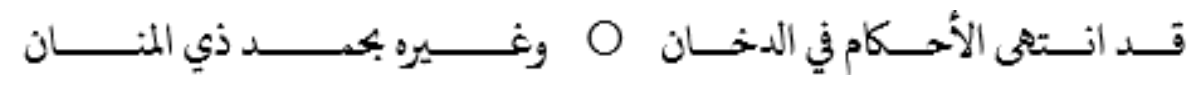

\begin{tabular}{|c|c|}
\hline Wa gairu bihamdin ż̀ al-manān & Qad intahā al-ahkām fi al-dukhāni \\
\hline $\begin{array}{c}\text { And others by praising those who } \\
\text { has philanthropy }\end{array}$ & The laws about smoking has finished \\
\hline
\end{tabular}

This verseaddresses that discussions on the law of smoking are over. Here the authorusesthe rhetorical tool kalām al-khabar al-talabi, the informative sentence addressed to the hearer who still hesitate and need clarity on the truth of the information delivered (Syarifudin, 2016: 241). The word al-talabi according to Salih (in Lesmana, 2009: 29-30) is a person who is doubtful about what is expressed by the speaker. So in this type of language an emphasis particle is required, but only one particle, قد (qad), is used in the verbal sentence qad intahā al-ahkām fi al-dukhāni. Looking at the purpose point of view, the purpose of the verse above is only as an ordinary informationwhich conveys that the discussion in the book is finished. In this verse, rhyme is also used at the end of the line which is the sound /-ni/ in the words /ad-dukhani/ and /al-manani/

Another verse about cigarettes is the following text:

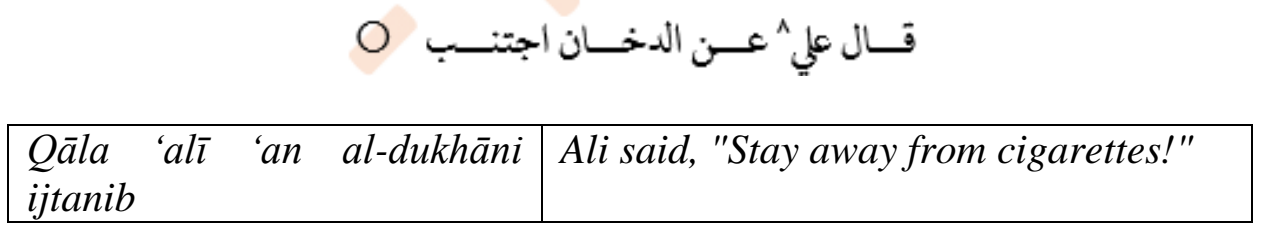

This verse explains about Ali's words telling us to keep away from cigarettes. This verse uses the tool of rhetoric kalam 'Insha, a statement that cannot be seen true or false because it is not delivered as an informative sentence or notification (Al-Jarim, 2013: 377). One of its kind is fi'il 'amr (imperative) that demands the execution of a task by a higher authority to a lowerauthority. (Al-Jarim, 2013: 251). In the verse above the imperative is lijtanib/ which means 'stay away. The purpose of the imperative mood in this sentence is irshād or giving directions.

Another example of poetry is the following text:

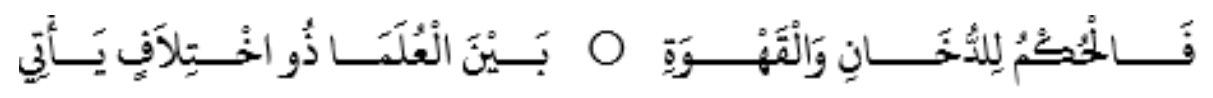

\begin{tabular}{|c|c|}
\hline $\begin{array}{l}\text { Bayna al-'ulamāa żü ikhtilāfin } \\
\text { ya'tī }\end{array}$ & $\begin{array}{l}\text { Fa al-hukmu li al-dukhāni wa al- } \\
\text { qahwati }\end{array}$ \\
\hline $\begin{array}{c}\text { Among scholars there is a } \\
\text { difference that is }\end{array}$ & the law of cigarettes and coffee \\
\hline
\end{tabular}

This verse is kalam al-khabar, because it is a statement that can be judged whether it true or alse. The goal of the verse is fa idat al-khabar, which provides information about the 
difference of opinionamong the scholars regarding the law of coffee drinking and smoking. In order to convey the information, it seems that the speaker does not feel the need to provide an emphasis particle, perhaps because the speaker is confident that the information delivered can be denied by the hearer. In this verse the author also uses the same rhyme /-ti/, in order to appeal to readers in addition to adding beauty to the words.

Next verse is the following text:

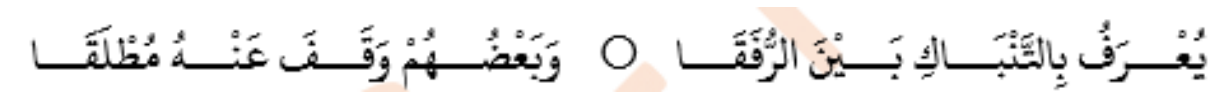

\begin{tabular}{|l|l|}
\hline $\begin{array}{l}\text { Wa ba'duhum waqafa 'anhu } \\
\text { mutlaqan }\end{array}$ & $\begin{array}{l}\text { Yu'rafu bi at-tanbak bayna ar- } \\
\text { rufaqa }\end{array}$ \\
\hline $\begin{array}{l}\text { And among them took a firm } \\
\text { stance against the problem }\end{array}$ & $\begin{array}{l}\text { The cigarette is known by the } \\
\text { name al-tanbāk among the } \\
\text { Companions }\end{array}$ \\
\hline
\end{tabular}

This verse explains that the cigarette is already known by the companions of the Prophet by the name al-tanbak, and then they take a firm stance on the matter. This verse uses the rhetorical tool of al-wasl, which is a combination of two clauses or sentences combined by using the connective particle /wal (Lesmana, 2009: 33). Al-Jarim (2013: 327) says that the use of $/ \mathrm{wa} /$ as a connecting support is due to three factors. The first factor iswhen the first and second sentences are the same in terms of their syntactic structure. The second factor iswhen both sentences are both informative sentences or equally not informative at all. Thirdly, if the connective particle /wa/ is not used, it will cause a misunderstanding in terms of its meaning. Another verse is the following text:

\begin{tabular}{|c|c|}
\hline Min ad-da'awi la dalilun qad yaramu & Wa da'wa kawwanahu li zatihi haramun \\
\hline are questionableclaims & $\begin{array}{l}\text { Claims about the forbiddance of } \\
\text { cigarettes due to its substances }\end{array}$ \\
\hline
\end{tabular}

This piece of poetry belongs to al-'itnāb tikrar. Al-Jarim (2013: 342) says that al'itna $\bar{b}$ is the addition of words, phrases, or clauses in a sentence to give further explanation. $A l$-'itnāb has its own technique in the making. It is called Tikrar because of the mention of a repeated word, specifically the word دعوى (claim) which is repeated with the word الدعاوى (claims). In this verse, the author also uses the same rhyme, the letter $/ \mathrm{mim} /$ which serves to embellish the verse and give attention to the reader.

Other verses about smoking are as follows:

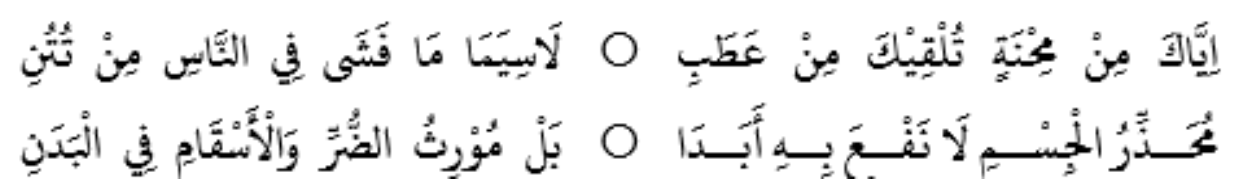

\begin{tabular}{|c|c|}
\hline $\begin{array}{l}\text { Lā siyamā mā fashā fi al-nāsi min } \\
\text { tutuni }\end{array}$ & 'iyyāka min mihnatin tulqüka min 'ațabi \\
\hline $\begin{array}{c}\text { Especially those already known by } \\
\text { humans, namely cigarette }\end{array}$ & $\begin{array}{c}\text { Beware of all the adversities that may } \\
\text { befall you }\end{array}$ \\
\hline DOI: 10.9790/0837-2206094957 & www.iosrjournals.org
\end{tabular}




\begin{tabular}{|c|c|}
\hline $\begin{array}{l}\text { Bal mūrisiu al-durra wa al 'asqāmi fi al- } \\
\text { badani }\end{array}$ & muhażżiru al-jismi lā naf'a bihi 'abadā \\
\hline $\begin{array}{l}\text { Even it brings harm and disease to the } \\
\text { body }\end{array}$ & $\begin{array}{l}\text { It harms the body andis of nobenefit at } \\
\text { all }\end{array}$ \\
\hline
\end{tabular}

This verse tells us to be careful of cigarettes, because it can be disastrous for us, it is not beneficial, it can harm our body and bring disease. In both verses, there is an element of al-qasr or restriction. As found in the first verse above, the clause Beware of all the adversities that may befall you is limited by the sentence especially known to humans, namely cigarettes. In this verse, the limiting particle is /la siyamal (especially). In the second verse, the clause it harms the body and is of no benefit at allis limited by the clause even it brings harm and disease to the body. The limitingparticle is /bal/ (even). In addition to that, these two verses also rhyme with the sound /-ni/. It seems that the rhyme of these two verses are also used to embellish the verse and give appeal to the reader.

Another verse is the following text:

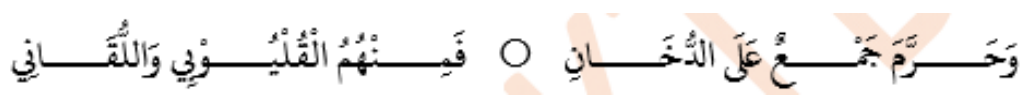

\begin{tabular}{|c|c|}
\hline Faminhum al-qulyūbì wa al-luqānī & Wa harrama jam'un 'alā al-dukhāni \\
\hline $\begin{array}{c}\text { Among them are al-Qulyūbi and al- } \\
\text { Luqāni }\end{array}$ & $\begin{array}{c}\text { A group of scholars have forbidden } \\
\text { smoking }\end{array}$ \\
\hline
\end{tabular}

This verse contains the opinion of a group of scholars who say that smoking is forbidden, among them are al-Qulyubi and al-Luqani. This verse is just plain information, because it does not use emphasis particles. Another rhetorical tool used in the verse is Al-fașl, a composite statement of two clauses, which between the two clauses are not connectedby using the connective particle/wal (and) (Lesmana, 2009: 33). The particle /wa/ is not used as a connective support between the two clauses, because the second clause confirms the first clause. The first clause is a group of scholars have forbidden smoking. This clause is actually a perfect sentence, judging from both of its structure and contents, but it is reaffirmed in the second clause: Among them are al-Qulyübi and al-Luqāni. The phrase of a group of scholarsis reaffirmed by the names of al-Qulyūbi and al-Luqāni. In the Arabic rhetorical rules, the combination of these two clauses should not be connected by using the connective particle /wa/ (and).

Another verse is the following text:

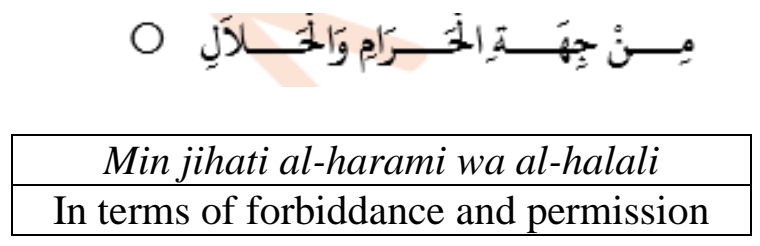

This verse is a piece from another verse that explains the law of coffee drinking and smoking from the forbidden (haram) and permissible (halal) aspects. This verse uses the rhetorical tool $T i b \bar{a} q$, which combines two words whose meaningsare contradictory in a statement. There are two kinds of tibāq, namely tibāq al-'ijābi and tibāa al-salbí. It is called tibāq al-'ijābiwhen the contradiction between the two words is not marked by the use of the word "no", and it is called tibāq al-salbīwhen the contradiction between the two words is 
marked by the use of the word "no" (Lesmana, 2009: 35). The opposite word in the above poetry piece is the word al-haräm which means forbiddance or unlawful and al-halāl which means is permission or lawful. This means that the tibaqused in this verse is tibaq ijabi.

The next verse is the following text:

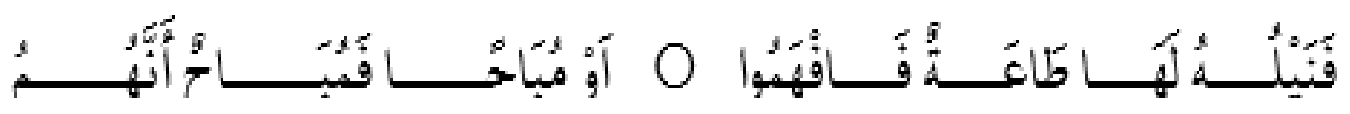

\begin{tabular}{|c|c|}
\hline 'aw mubahan famubahun 'annahum & Fanayluhu laha ta'atun fafhamu \\
\hline $\begin{array}{c}\text { Or if coffee drinking is something that } \\
\text { is allowed, then do it }\end{array}$ & If coffee drinking is a must, then \\
follow it
\end{tabular}

In this verse it is explained that if the law of coffee drinking isa necessity then follow it. Likewise, if coffee drinking is allowed, then it is permissible to drink it. This verse uses the rhetorical tool of muqabalah, which is the presence of two or more words at the beginning of the sentence, followed by words whose meaning is contradictory to the end of the sentence (Al-Jarim, 2013: 409). In this verse, there are two contradictory phrases, the first one isif coffee drinking is a necessity, then follow it and the second one isor if coffee drinking is something that is allowed, then do it.

This concludes the discussion of the structure and content of the literary texts written in this book.

\section{CONCLUSION}

Based on the information above, this article finds that although the book uses literary texts in conveying information about coffee and smoking laws, the diction used are more denotative words rather than connotative ones, as well as literal words rather than figurative ones, thus making it easier to digest by the public. This is consistent withthe statement of Sumardjo and Saini KM'sregarding the presence of non-imaginative literature which emphasises the faculty elements rather than imagination and is supported by a language style with a denotative tendency. Although there are connotative elements present in the book, they are very dependent on the style of writing of the author (Wicaksono, 2014: 17).

This article also views that the choice of Classic arabic poetry as a means to convey ideas about the law of coffee drinking and smoking is appropriate. This is due to the fact that the form of classic Arabic poetry is simpler than the modern poetry, so it can convey ideas well and adequately. Classic Arabicpoetry generally consists of dozens or even thousands of verses and one verse consists of only one line, so it is sufficient to convey as much information as possible.Meanwhile,classic Arabic poems with short verses may have of a stanza, which consists of several lines, since there is line breaks of enjambmentto truncate the particular poem. This type of poem would be difficult to use as a tool in order to convey the desired ideas.

The rhetorical aspects used in literary texts in the book also use more of the literal words rather than figurative ones, so that the readers do not findthe unnecessary difficulty to understand the text. The slight problem is the style of writing, because the book is presented with a classic prose writing style that does not use punctuation. This will be a bit difficult for today's readers who are unfamiliar with such a form. In fact, many of themodern-day books have now applied the style of modern writing that uses punctuations. 


\section{BIBLIOGRAPHIES}

(1) Al-Jarim, A., \& Amin, M. (2013). Terjemahan Al-Balaaghatul Waadhihah. Bandung: Penerbit Sinar Baru Algesindo.

(2) Hadi, M. (2008). Jejak Spiritual Kiai Jampes. Yogyakarta: Pustaka Pesantren.

(3) Jampes, I. I. (2009). Kitab Kopi dan Rokok. (A. Murtadho, \& M. Dje, translator) Yogyakarta: Pustaka Pesantren.

(4) (2013). Irshādu al-Ikhwāni Libayāni Shurbi Al-Qahwati Wa Ad-Dhukhāni. (PISS-KTB, Penyunt.) Yogyakarta: PISS-KTB.

(5) Lesmana, Maman. (2009). Kitāb Al-Bukhalā' Analisis Struktur Teks dan Isi. Depok: The Faculty of Humanities, Universitas Indonesia.

(6) Lesmana, Maman. (2010). Kritik Sastra Arab dan Islam. Depok: The Faculty of Humanities, Universitas Indonesia.

(7) Syarifuddin, Bahruddin, M. S., Azizah, M., Muthohharoh, M., Qamariyah, N. L., \& Ni'mah, N. (2016). Kamus Istilah Ilmu Balaghah. Yogyakarta: AG Publisher.

(8) Wasid. (2016). Tasawuf Nusantara Kiai Ihsan Jampes. Surabaya: Pustaka Idea.

(9) Wicaksono, Andri (2014), Pengkajian Prosa Fiksi, Garudhawaca

(10) Napster, Hadi,Dampak Licentia Poetica Bernama Kredo Puisi Terhadap Eksistensi Bahasa http://www.kompasiana.com/downloaded on 11 May 2017 01:09:41 